\title{
Streptomyces siamensis sp. nov., and Streptomyces similanensis sp. nov., isolated from Thai soils
}

\author{
Paranee Sripreechasak $^{1}$, Atsuko Matsumoto ${ }^{2}$, Khanit Suwanborirux ${ }^{3}$, Yuki Inahashi ${ }^{2}$, Kazuro Shiomi ${ }^{2,4}$, \\ Somboon Tanasupawat ${ }^{1}$ and Yoko Takahashi ${ }^{2,4}$
}

Three actinomycete strains, $\mathrm{KC}-038^{\top}, \mathrm{KC}-031$ and $\mathrm{KC}-106^{\top}$, were isolated from soil samples collected in the southern Thailand. The morphological and chemotaxonomic properties of strains $\mathrm{KC}-038^{\top}, \mathrm{KC}-031$ and $\mathrm{KC}-106^{\top}$ were consistent with the characteristics of members of the genus Streptomyces, that is, the formation of aerial mycelia bearing spiral spore chains; the presence of LL-diaminopimelic acid in the cell wall, MK-9 $\left(\mathrm{H}_{6}\right)$, MK-9 $\left(\mathrm{H}_{4}\right)$ and MK-9 $\left(\mathrm{H}_{8}\right)$ as the predominant menaquinones; and $\mathrm{C}_{16: 0}$, iso- $\mathrm{C}_{16: 0}$ and anteiso- $\mathrm{C}_{15: 0}$ as the major cellular fatty acids. 16S rRNA gene sequence analyses indicated that strains KC-038 ${ }^{\top}$ and $\mathrm{KC}-031$ were highly similar $(99.9 \%)$, and they were closely related to $S$. olivochromogenes NBRC $3178^{\top}$ (98.1\%) and S. psammoticus NBRC $13971^{\top}(98.1 \%)$. Strain KC-106 ${ }^{\top}$ was closely related to S. seoulensis NBRC $16668^{\top}$ $(98.9 \%)$, S. recifensis NBRC $12813^{\top}(98.9 \%)$, S. chartreusis NBRC $12753^{\top}(98.7 \%)$ and S. griseoluteus NBRC $13375^{\top}$ (98.4\%). The values of DNA-DNA relatedness between the isolates and the type strains of the related species were below $70 \%$. On the basis of the polyphasic evidence, the isolates should be classified as two novel species, namely Streptomyces siamensis sp. nov. (type strain, $\mathrm{KC}-038^{\top}=$ NBRC $108799^{\top}=$ PCU $328^{\top}=$ TISTR $2107^{\top}$ ) and Streptomyces similanensis sp. nov. (type

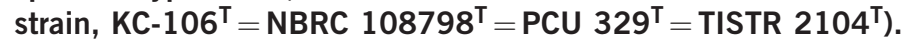

The Journal of Antibiotics (2013) 66, 633-640; doi:10.1038/ja.2013.60; published online 12 June 2013

Keywords: new species; polyphasic taxonomy; Streptomycetaceae; Streptomyces siamensis; Streptomyces similanensis

\section{INTRODUCTION}

The genus Streptomyces belonging to the family Streptomycetaceae was proposed by Waksman and Henrici ${ }^{1}$ to accommodate aerobic, Grampositive and spore-forming actinomycetes. The Streptomyces strains represent a group of actinomycetes that are widely distributed in nature. At present, the genus comprises more than 550 recognized species with validly published names, and recently some novel species, including S. cocklensis, ${ }^{2}$ S. gramineus, ${ }^{3}$ S. nanhaiensis, ${ }^{4}$ S. panacagri, ${ }^{5}$ S. pharmamarensis, ${ }^{6}$ S. qinglanensis $^{7}$ and S. staurosporininus, ${ }^{8}$ have been described. Strains of the genus Streptomyces are superior to other actinomycete strains in their ability to produce various bioactive metabolites, especially antibiotics. Well-known antibiotics derived from Streptomyces strains include tetracycline, streptomycin, chloramphenicol, neomycin, nystatin, amphotericin, kanamycin and cycloheximide. Streptomyces strains are still a rich source of commercially significant compounds, such as antibiotics, enzymes, enzyme inhibitors and other pharmacologically active agents. ${ }^{9}$ Therefore, new species in the genus Streptomyces remains a focus of efficient research for the discovery of new bioactive compounds. In this paper, we report the taxonomic status of Streptomyces strains
KC- $038^{\mathrm{T}}$, KC-031 and KC-106 ${ }^{\mathrm{T}}$, which were isolated from soils in the south of Thailand.

\section{MATERIALS AND METHODS}

Strains KC- $038^{\mathrm{T}}$ and KC-031 were isolated from soil samples collected from the Krung Ching Waterfall, Khao Luang National Park, Nakhon Si Thammarat Province, Thailand, and strain KC-106 ${ }^{\mathrm{T}}$ was isolated from the Similan Island National Park $\left(8^{\circ} 39^{\prime} 09^{\prime \prime} \mathrm{N} 97^{\circ} 38^{\prime} 27^{\prime \prime} \mathrm{E}\right)$, Phanga Province, Thailand. The soil samples were serially diluted with distilled water, heated at $55^{\circ} \mathrm{C}$ for $5 \mathrm{~min}$ and plated onto potato starch-glycerol agar ${ }^{10}$ and starch casein nitrate agar ${ }^{11}$ containing nystatin $\left(25 \mathrm{mgl}^{-1}\right)$ and tetracycline $\left(10 \mathrm{mgl}^{-1}\right)$. The resulting pure isolates were maintained on SYM agar (starch $1.0 \%$, NZ amine $0.3 \%$, yeast extract $0.1 \%$, meat extract $0.1 \%, \mathrm{CaCO}_{3} 0.3 \%$, agar $1.2 \%, \mathrm{pH} 7.0$ ). Genomic DNA of each isolate was obtained by sonication of a suspension of cells ${ }^{12}$ grown in YD broth (yeast extract 1.0\%, dextrose 1.0\%, pH 7.0). The $16 \mathrm{~S}$ rRNA gene was amplified using the primers described by Takahashi et al. ${ }^{13}$ The PCR products were sequenced on a DNA sequencer (model 3130 Genetic Analyzer; Applied Biosystems, Foster City, CA, USA) using a BigDye Terminator v3.1 Cycle Sequencing Kit (Applied Biosystems), according to the manufacturer's instructions. The closest phylogenetic neighbors were identified by BLAST searches using the EzTaxon-e server. ${ }^{14}$ The clustalw2

\footnotetext{
${ }^{1}$ Department of Biochemistry and Microbiology, Faculty of Pharmaceutical Sciences, Chulalongkorn University, Bangkok, Thailand; ${ }^{2}$ Kitasato Institute for Life Sciences, Kitasato University, Minato-ku, Tokyo, Japan; ${ }^{3}$ Department of Pharmacognosy and Pharmaceutical Botany, Faculty of Pharmaceutical Sciences, Chulalongkorn University, Bangkok, Thailand and ${ }^{4}$ Graduate School of Infection Control Sciences, Kitasato University, Minato-ku, Tokyo, Japan

Correspondence: Dr S Tanasupawat, Department of Biochemistry and Microbiology, Faculty of Pharmaceutical Sciences, Chulalongkorn University, Bangkok 10330, Thailand. E-mail: somboon.t@chula.ac.th

or Dr Y Takahashi, Kitasato Institute for Life Sciences, Kitasato University, 5-9-1 Shirokane, Minato-ku, Tokyo 108 8641, Japan.

E-mail: ytakaha@lisci.kitasato-u.ac.jp
}

Received 4 January 2013; revised 2 May 2013; accepted 9 May 2013; published online 12 June 2013 
program was used for multiple alignments with selected sequences for calculating evolutionary distances ${ }^{15}$ with SeaView version 4.2. ${ }^{16}$ Phylogenetic trees were constructed using the neighbour-joining, ${ }^{17}$ maximum-likelihood ${ }^{18}$

Table 1 Cellular fatty acid compositions (\%) of strains $\mathrm{KC}-038^{\top}$, $\mathrm{KC}-031$ and closely related type strains

\begin{tabular}{|c|c|c|c|c|}
\hline Fatty acid & $K C-038^{T}$ & $K C-031$ & $\begin{array}{l}\text { S. olivochromogenes } \\
\text { NBRC } 3178^{T}\end{array}$ & $\begin{array}{l}\text { S. psammoticus } \\
\text { NBRC } 13971^{T}\end{array}$ \\
\hline \multicolumn{5}{|c|}{ Saturated straight chain } \\
\hline $\mathrm{C}_{14: 0}$ & 4.0 & 3.0 & 0.7 & 3.2 \\
\hline$C_{16: 0}$ & 23.5 & 19.7 & 7.6 & 23.9 \\
\hline$C_{17: 0}$ & 1.2 & 1.0 & 0.5 & 1.0 \\
\hline $\mathrm{C}_{18: 0}$ & - & - & - & 0.5 \\
\hline $\mathrm{C}_{17: 0}$ cyclo & 0.5 & 0.7 & 2.9 & 3.7 \\
\hline \multicolumn{5}{|c|}{ Unsaturated straight chain } \\
\hline $\mathrm{C}_{17: 1} \omega 8 \mathrm{c}$ & 0.6 & 0.6 & - & - \\
\hline \multicolumn{5}{|c|}{ Saturated branched chain } \\
\hline iso- $\mathrm{C}_{14: 0}$ & 8.6 & 8.5 & 8.0 & 2.0 \\
\hline iso- $\mathrm{C}_{15: 0}$ & 7.7 & 8.9 & 13.0 & 10.8 \\
\hline iso- $\mathrm{C}_{16: 0}$ & 18.4 & 22.3 & 22.1 & 10.5 \\
\hline iso- $\mathrm{C}_{17: 0}$ & 1.7 & 2.7 & 4.9 & 2.9 \\
\hline iso- $\mathrm{C}_{18: 0}$ & - & - & 0.9 & 0.6 \\
\hline anteiso- $\mathrm{C}_{13: 0}$ & 0.5 & $\bar{c}$ & - & $\overline{0}$ \\
\hline anteiso- $\mathrm{C}_{15: 0}$ & 17.7 & 16.6 & 25.2 & 22.6 \\
\hline anteiso- $\mathrm{C}_{17: 0}$ & 4.2 & 4.6 & 6.7 & 9.8 \\
\hline \multicolumn{5}{|c|}{ Unsaturated branched chain } \\
\hline iso- $\mathrm{C}_{16: 1} \mathrm{H}$ & 0.6 & 0.9 & 1.0 & - \\
\hline iso- $C_{17: 1} \omega 9 c$ & 0.6 & 1.0 & 1.9 & 0.5 \\
\hline $\begin{array}{l}\text { anteiso- } C_{17: 1} \\
\omega 9 c\end{array}$ & 0.5 & 0.6 & 1.2 & 0.7 \\
\hline $\begin{array}{l}\text { Summed } \\
\text { feature }^{\text {a } 3}\end{array}$ & 6.0 & 5.5 & 1.2 & 4.4 \\
\hline
\end{tabular}

and maximum-parsimony ${ }^{19}$ methods. Data were resampled with 1000 bootstrap replications. ${ }^{20}$ Values for sequence similarity among the closely related strains were determined using the EzTaxon-e server. ${ }^{14}$

Table 2 Cellular fatty acid compositions (\%) of strain $\mathrm{KC}-106^{\top}$ and closely related type strains

\begin{tabular}{|c|c|c|c|c|c|}
\hline & & $\begin{array}{c}\text { S. seoulensis } \\
\text { NBRC }\end{array}$ & $\begin{array}{c}\text { S. recifensis } \\
\quad N B R C\end{array}$ & $\begin{array}{c}\text { S. griseoluteus } \\
\text { NBRC }\end{array}$ & $\begin{array}{c}\text { S. chartreusis } \\
\text { NBRC }\end{array}$ \\
\hline Fatty acid & $K C-106^{T}$ & $16668^{T}$ & $12813^{T}$ & $13375^{T}$ & $12753^{T}$ \\
\hline \multicolumn{6}{|c|}{ Saturated straight chain } \\
\hline $\mathrm{C}_{14: 0}$ & 0.6 & 0.8 & - & 0.8 & 2.0 \\
\hline $\mathrm{C}_{16: 0}$ & 5.4 & 4.4 & 5.7 & 8.5 & 9.7 \\
\hline $\mathrm{C}_{18: 0}$ & 1.1 & 2.1 & 0.6 & - & - \\
\hline $\mathrm{C}_{17: 0}$ cyclo & 2.0 & 2.4 & 3.3 & 1.8 & 0.4 \\
\hline \multicolumn{6}{|c|}{ Unsaturated straight chain } \\
\hline $\mathrm{C}_{18: 1} \omega 9 c$ & - & 2.2 & - & - & - \\
\hline \multicolumn{6}{|c|}{ Saturated branched chain } \\
\hline iso- $\mathrm{C}_{14: 0}$ & 5.8 & 10.2 & 6.7 & 4.2 & 7.3 \\
\hline iso- $\mathrm{C}_{15: 0}$ & 8.6 & 8.9 & 10.6 & 9.3 & 11.6 \\
\hline iso- $C_{16: 0}$ & 23.2 & 20.1 & 19.3 & 17.9 & 19.8 \\
\hline iso- $\mathrm{C}_{17: 0}$ & 3.3 & 1.1 & 3.6 & 2.8 & 2.4 \\
\hline iso- $\mathrm{C}_{18: 0}$ & 1.5 & 1.0 & 1.5 & 1.1 & - \\
\hline anteiso- $\mathrm{C}_{13: 0}$ & ND & - & - & 0.6 & 1.3 \\
\hline anteiso- $\mathrm{C}_{15: 0}$ & 25.0 & 26.2 & 29.3 & 29.9 & 2.8 \\
\hline anteiso- $\mathrm{C}_{17: 0}$ & 10.3 & 4.2 & 8.0 & 13.6 & 5.8 \\
\hline \multicolumn{6}{|c|}{ Unsaturated branched chain } \\
\hline iso- $\mathrm{C}_{16: 1} \mathrm{H}$ & 4.4 & 5.9 & 2.2 & 1.3 & 1.6 \\
\hline iso- $\mathrm{C}_{17: 1} \omega 9 c$ & 1.6 & 1.7 & 2.2 & 1.7 & 1.4 \\
\hline $\begin{array}{l}\text { anteiso- } \mathrm{C}_{17: 1} \\
\omega 9 c\end{array}$ & 4.1 & 4.3 & 3.2 & 2.6 & 1.2 \\
\hline $\begin{array}{l}\text { Summed } \\
\text { feature }{ }^{a} 3\end{array}$ & 0.9 & 2.0 & 1.4 & 2.2 & 6.9 \\
\hline
\end{tabular}



Figure 1 Neighbour-joining phylogenetic tree based on 16S rRNA gene sequences showing the relationship between strains $\mathrm{KC}^{-0} 038^{\top}$, KC-031 and closely related type strains of the genus Streptomyces. Only bootstrap values above 50\% (percentages of 1000 replications) are indicated. (O), branches were also recovered in the maximum-parsimony tree; $(*)$, branches were also recovered in the maximum-likelihood tree; Bar, 0.005 nucleotide substitutions per site. 
Strains KC- $038^{\mathrm{T}}, \mathrm{KC}-031$ and $\mathrm{KC}-106^{\mathrm{T}}$ were cultivated at $27^{\circ} \mathrm{C}$ for 2 weeks on ISP (International Streptomyces Project) 2, 3, 4, 5, 6 and 7 media, ${ }^{21}$ YS agar (yeast extract $2.0 \%$, starch $1.0 \%$, agar $1.5 \%, \mathrm{pH} 7.0$ ) and nutrient agar. The Color Harmony Manual ${ }^{22}$ was used to determine the color of aerial and substrate mycelia and soluble pigment. The features of the substrate and aerial mycelia and spores were observed by light microscopy (Nikon; model Labophoto-2, Tokyo, Japan) and scanning electron microscopy (model JSM5600 , JEOL, Tokyo, Japan) after cultivation on agar media at $27^{\circ} \mathrm{C}$ for 3 weeks. For scanning electron microscopy investigation, the cultures were fixed with $4 \%$ osmium tetraoxide vapor in situ for $16 \mathrm{~h}$ at room temperature, and then dried at room temperature. ${ }^{23}$ Physiological characteristics, $\mathrm{NaCl}$ tolerance, and the temperature and $\mathrm{pH}$ ranges required for growth were determined on ISP 2 medium. Utilization of various carbohydrates as the sole carbon source was tested using ISP 9 medium. ${ }^{24}$ Starch hydrolysis was examined using ISP 4 medium, while nitrate medium (beef extract $0.3 \%$, peptone $0.5 \%, \mathrm{KNO}_{3} 0.1 \%$, $\mathrm{pH}$ 7.0) was used to assess nitrate reduction, and glucose-peptone-gelatin medium (glucose $2.0 \%$, peptone $0.5 \%$, gelatin $20 \%, \mathrm{pH} 7.0$ ) was used to examine gelatin liquefaction. Skim milk (10\%) was used to assess coagulation and peptonization of milk, and skim milk agar was used to examine casein hydrolysis. Enzyme activities were determined using the API ZYM system (bioMérieux, Lyon, France), according to the manufacturer's instructions. Biomass for the genotypic and chemotaxonomic studies was obtained after cultivation in YD broth on a rotary shaker at $27^{\circ} \mathrm{C}$ for 3 days. Diaminopimelic acid isomers in whole cells were determined by TLC using whole-cell hydrolysates. ${ }^{25}$ Whole-cell sugar composition was analyzed according to the methods of Becker et al..$^{25}$ Isoprenoid quinones were extracted according to the method of Collins et al. ${ }^{26}$, and were analyzed by LC/MS (JMS-T 100LP, JEOL) using a CAPCELL PAK C18 UG120 column (Shiseido, Tokyo, Japan) with methanol/2-propanol (7:3). The $\mathrm{N}$-acyl types of muramic acid were determined by using the method of Uchida and Aida. ${ }^{27}$ Phospholipids were extracted and identified by using the method of Minnikin $e t$ al. ${ }^{28}$ The presence of mycolic acids was examined by TLC following the protocol of Tomiyasu. ${ }^{29}$ Cellular fatty acid composition was determined by gas liquid chromatography, according to the Microbial Identification System (MIDI) Sherlock version 6.0 using the RTSBA6 MIDI database as described by Sasser. ${ }^{30}$ For DNA base composition analysis, chromosomal DNA was prepared following the procedure of Saito and Miura, ${ }^{31}$ and the DNA G+C content was determined by HPLC according to the method of Tamaoka and Komagata. ${ }^{32}$ DNA-DNA hybridization was performed using the photobiotin-labeling method of Ezaki et al. ${ }^{33}$

\section{RESULTS AND DISCUSSION}

\section{Chemotaxonomic characteristics}

Strains KC-038 ${ }^{\mathrm{T}}$, KC-031 and KC-106 ${ }^{\mathrm{T}}$ exhibited typical characteristics of the genus Streptomyces. LL-diaminopimelic acid was detected in whole-cell hydrolysates. The menaquinones detected were as follows: MK-9 $\left(\mathrm{H}_{6}\right)(62 \%)$, MK-9 $\left(\mathrm{H}_{4}\right)(23 \%)$ and MK-9 $\left(\mathrm{H}_{8}\right)(15 \%)$ for KC$038^{\mathrm{T}}$, and MK-9 $\left(\mathrm{H}_{8}\right)(70 \%)$, MK-9 $\left(\mathrm{H}_{6}\right)(21 \%)$ and MK-9 $\left(\mathrm{H}_{4}\right)$ $(10 \%)$ for $\mathrm{KC}-106^{\mathrm{T}}$. The $\mathrm{N}$-acyl type of muramic acid was acetyl. Strains $\mathrm{KC}-038^{\mathrm{T}}$ and $\mathrm{KC}-106^{\mathrm{T}}$ contained diphosphatidylglycerol, phosphatidylethanolamine, phosphatidylglycerol, phosphatidylinositol and unknown phospholipids as phospholipid composition. Strains

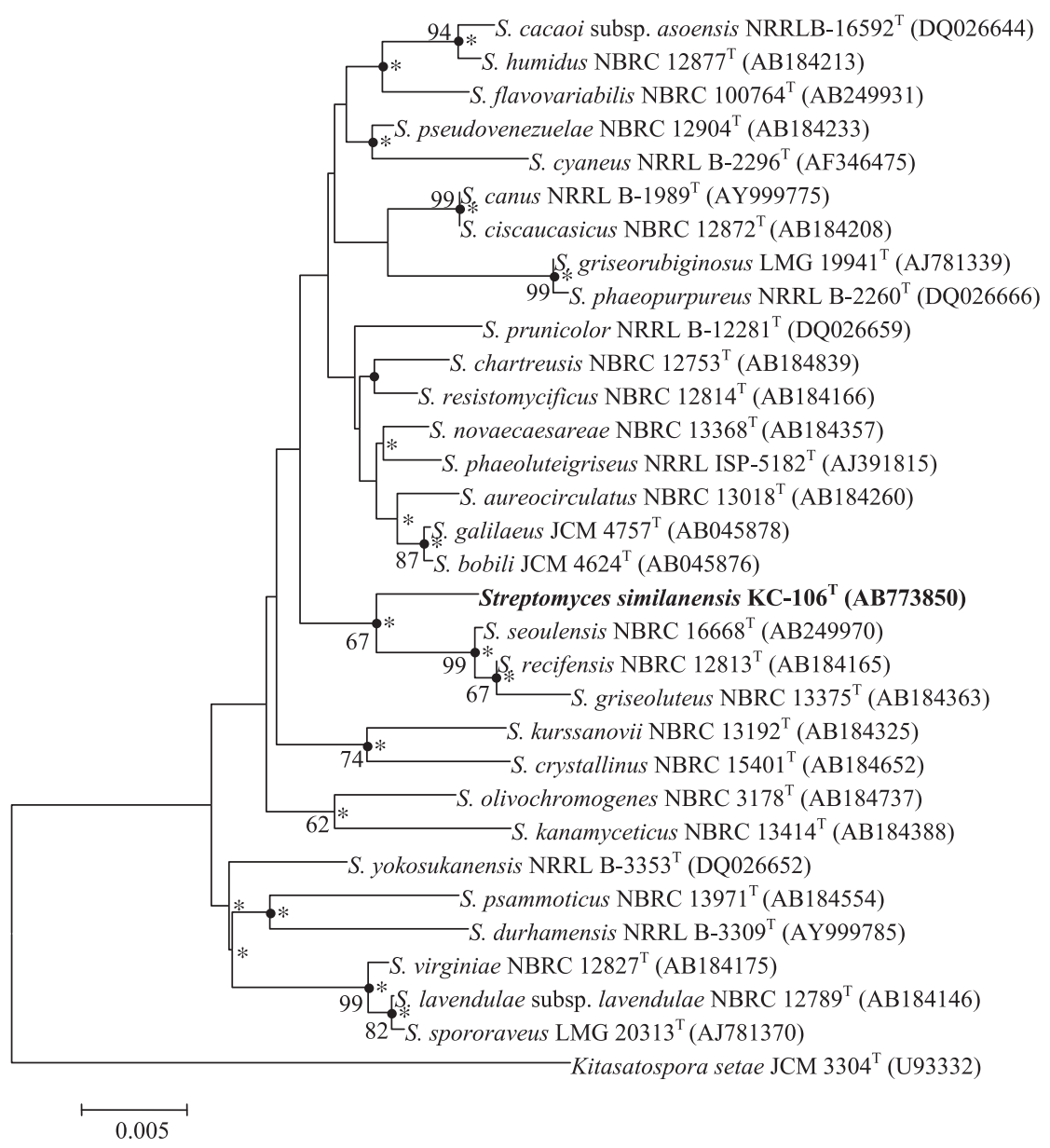

Figure 2 Neighbour-joining phylogenetic tree based on 16S rRNA gene sequences showing the relationship between strain KC-106 ${ }^{\top}$ and closely related type strains of the genus Streptomyces. Only bootstrap values above 50\% (percentages of 1000 replications) are indicated. ( ), branches were also recovered in the maximum-parsimony tree; $\left({ }^{*}\right)$, branches were also recovered in the maximum-likelihood tree; Bar, 0.005 nucleotide substitutions per site. 
Table 3 Cultural characteristics of strains $\mathrm{KC}-038^{\mathrm{T}}, \mathrm{KC}-031$ and closely related type strains

\begin{tabular}{|c|c|c|c|c|}
\hline \multirow[b]{2}{*}{ Medium } & \multirow[b]{2}{*}{$K C-038^{T}$} & \multirow[b]{2}{*}{$K C-031$} & \multirow{2}{*}{$\begin{array}{l}\text { S. olivochromogenes } \\
\text { NBRC } 3178^{T}\end{array}$} & \multirow{2}{*}{$\begin{array}{l}\text { S. psammoticus NBRC } \\
13971^{T}\end{array}$} \\
\hline & & & & \\
\hline \multicolumn{5}{|l|}{ ISP medium 2} \\
\hline Growth & $\begin{array}{l}\text { Good } \\
\text { Mustard (2le) }\end{array}$ & $\begin{array}{l}\text { Good } \\
\text { Bamboo (2gc) to mustard } \\
\text { (2le) }\end{array}$ & $\begin{array}{l}\text { Good } \\
\text { Bamboo (2gc) }\end{array}$ & $\begin{array}{l}\text { Good } \\
\text { Bamboo (2gc) }\end{array}$ \\
\hline Reverse & Golden olive (2lg) to beaver ( $3 \mathrm{li}$ ) & Camel (3ie) to bamboo (2gc) & Bamboo (2gc) & Bamboo (2gc) \\
\hline Aerial mycelium & $\begin{array}{l}\text { Abundant, white (a) to ashes } \\
(5 \mathrm{fe})\end{array}$ & Moderate, white (a) & Poor, white (a) & Moderate, white (a) \\
\hline Soluble pigment & None & None & None & None \\
\hline \multicolumn{5}{|l|}{ ISP medium 3} \\
\hline \multirow[t]{2}{*}{ Growth } & Good & Good & Good & Good \\
\hline & $\begin{array}{l}\text { Light antique gold }\left(1_{1 / 2} \text { ic }\right) \text { to } \\
\text { antique gold }\left(1_{1 / 2} \text { ne }\right)\end{array}$ & Light mustard tan (2ie) & $\begin{array}{l}\text { Ivory (2db) to mustard } \\
(2 l e)\end{array}$ & Yellow maple (3ng) \\
\hline Reverse & $\begin{array}{l}\text { Light antique gold }\left(1_{1 / 2} \text { ic }\right) \text { to } \\
\text { mustard tan }(2 \mathrm{lg})\end{array}$ & $\begin{array}{l}\text { Mustard (2le) to mustard tan } \\
(2 \mathrm{lg})\end{array}$ & $\begin{array}{l}\text { Ivory }(2 \mathrm{db}) \text { to mustard } \\
(2 \mathrm{le})\end{array}$ & Camel or $\tan (3 i e)$ \\
\hline Aerial mycelium & Abundant, slate $\tan (2 \mathrm{ig})$ & $\begin{array}{l}\text { Abundant, beige (3ge) to } \\
\text { slate tan ( } 2 \text { ig) }\end{array}$ & Moderate, white (a) & $\begin{array}{l}\text { Abundant, white (a) to sand } \\
(3 \mathrm{cb})\end{array}$ \\
\hline Soluble pigment & None & None & None & None \\
\hline \multicolumn{5}{|l|}{ ISP medium 4} \\
\hline \multirow[t]{2}{*}{ Growth } & Good & Good & Good & Good \\
\hline & Antique gold $\left(1_{1 / 2}\right.$ ne $)$ & $\begin{array}{l}\text { Light mustard } \tan (2 \mathrm{ie}) \text { to } \\
\text { mustard } \tan (2 \mathrm{lg})\end{array}$ & Mustard (2le) & Mustard tan (2ie) \\
\hline Reverse & $\begin{array}{l}\text { Light mustard tan (2ie) to mus- } \\
\text { tard } \tan (2 n g)\end{array}$ & Mustard brown (2pi) & Bamboo (2gc) & Bamboo (2gc) \\
\hline Aerial mycelium & $\begin{array}{l}\text { Abundant, natural (3dc) to silver } \\
\text { gray (3fe) }\end{array}$ & Abundant, silver gray ( $3 f e$ ) & None & Moderate, white (a) \\
\hline Soluble pigment & None & None & None & None \\
\hline \multicolumn{5}{|l|}{ ISP medium 5} \\
\hline \multirow[t]{2}{*}{ Growth } & Good & Good & Good & Good \\
\hline & $\begin{array}{l}\text { Biscuit ( } 2 \mathrm{ec} \text { ) to antique gold ( } 1_{1 /} \\
\text { 2ne) }\end{array}$ & Sand $(3 c b)$ & White (a) & Pearl (3ba) \\
\hline Reverse & $\begin{array}{l}\text { Biscuit (2ec) to light mustard tan } \\
\text { (2ie) }\end{array}$ & Biscuit (2ec) & White (a) & Pearl (3ba) \\
\hline Aerial mycelium & Abundant, beige (3gc) & Abundant, sand (3cb) & Poor, white (a) & Abundant, white (a) \\
\hline Soluble pigment & None & None & None & None \\
\hline \multicolumn{5}{|l|}{ ISP medium 6} \\
\hline \multirow[t]{2}{*}{ Growth } & Good & Good & Good & Good \\
\hline & Chocolate $(4 n \mathrm{l})$ & Light mustard tan (2ie) & Bamboo (2gc) & Honey gold (2ic) \\
\hline Reverse & Chocolate (4nl) & Light mustard tan (2ie) & Bamboo (2gc) & Honey gold (2ic) \\
\hline Aerial mycelium & None & None & None & None \\
\hline Soluble pigment & Chocolate brown (4pn) & Mustard gold (2pg) & None & Amber (3pc) \\
\hline \multicolumn{5}{|l|}{ ISP medium 7} \\
\hline \multirow[t]{2}{*}{ Growth } & Good & Good & Good & Good \\
\hline & $\begin{array}{l}\text { Biscuit (2ec) to dusty yellow } \\
\text { (2gc) }\end{array}$ & Convert tan (2ge) & White (a) & Pearl (3ba) \\
\hline Reverse & $\begin{array}{l}\text { Natural (3dc) to antique gold } \\
\left(1_{1 / 2} \text { ne }\right)\end{array}$ & Natural (3dc) & White (a) & Pearl (3ba) \\
\hline Aerial mycelium & Abundant, beige (3ge) & Abundant, natural (3dc) & Moderate, white (a) & Abundant, white (a) \\
\hline Soluble pigment & None & None & None & None \\
\hline \multicolumn{5}{|l|}{ YS agar } \\
\hline \multirow[t]{2}{*}{ Growth } & Good & Good & Good & Good \\
\hline & $\begin{array}{l}\text { Biscuit (2ec) to chartreuse yel- } \\
\text { low ( } 2 \mathrm{ie})\end{array}$ & Bamboo (2gc) & Cream $\left(1_{1 / 2} \mathrm{ca}\right)$ & Mustard tan (2ie) \\
\hline Reverse & $\begin{array}{l}\text { Bamboo (2gc) to light mustard } \\
\tan (2 \mathrm{ie})\end{array}$ & Bamboo (2gc) & Cream $\left(1_{1 / 2} \mathrm{ca}\right)$ & $\begin{array}{l}\text { Bamboo (2gc) to mustard tan } \\
(2 \mathrm{ie})\end{array}$ \\
\hline Aerial mycelium & $\begin{array}{l}\text { Abundant, white to slate tan } \\
\text { (2ig) }\end{array}$ & Moderate, slate tan (2ig) & None & Abundant, white (a) \\
\hline Soluble pigment & None & None & None & None \\
\hline \multicolumn{5}{|l|}{ Nutrient agar } \\
\hline \multirow{2}{*}{ Growth } & Good & Good & Good & Good \\
\hline & Cream $\left(1_{1 / 2} \mathrm{ca}\right)$ & Cream $\left(1_{1 / 2} \mathrm{ca}\right)$ & $\begin{array}{l}\text { Cream }\left(1_{1 / 2} \mathrm{ca}\right) \text { to bamboo } \\
(2 \mathrm{gc})\end{array}$ & Cream $\left(1_{1 / 2} \mathrm{ca}\right)$ \\
\hline Reverse & $\begin{array}{l}\text { Cream }\left(1_{1 / 2} \mathrm{ca}\right) \text { to light ivory } \\
\text { (2ca) }\end{array}$ & Cream $\left(1_{1 / 2} \mathrm{ca}\right)$ & $\begin{array}{l}\text { Cream }\left(1_{1 / 2} \mathrm{ca}\right) \text { to bamboo } \\
(2 \mathrm{gc})\end{array}$ & Cream $\left(1_{1 / 2} \mathrm{ca}\right)$ \\
\hline Aerial mycelium & Poor, white (a) & None & None & Poor, white (a) \\
\hline Soluble pigment & None & None & None & None \\
\hline
\end{tabular}

Numbers and letters in parentheses referred to the color based on the Color Harmony Manual. ${ }^{22}$

KC- $038^{\mathrm{T}}$ and KC-031 contained $\mathrm{C}_{16: 0}(23.5,19.7 \%)$, iso- $\mathrm{C}_{16: 0}(18.4$, $22.3 \%)$ and anteiso- $\mathrm{C}_{15: 0}(17.7,16.6 \%)$ (Table 1), whereas strain $\mathrm{KC}$ $106^{\mathrm{T}}$ contained anteiso- $\mathrm{C}_{15: 0}(25.0 \%)$, iso- $\mathrm{C}_{16: 0}(23.2 \%)$ and anteiso$\mathrm{C}_{17: 0}(10.3 \%)$ as major cellular fatty acids (Table 2$)$. The cellular fatty acid profiles of strains $\mathrm{KC}-038^{\mathrm{T}}$, KC- 031 and $\mathrm{KC}-106^{\mathrm{T}}$ were almost the same as those of the type strains, but the amount of some fatty acids was different, as shown in Tables 1 and 2. The DNA G $+\mathrm{C}$ content was $72 \mathrm{~mol} \%$ for strains $\mathrm{KC}-038^{\mathrm{T}}$ and $\mathrm{KC}-031$, and $73 \mathrm{~mol} \%$ for strain $\mathrm{KC}-106^{\mathrm{T}}$.

\section{Phylogenetic analysis}

The 16S rRNA gene sequence similarity value between strains KC$038^{\mathrm{T}}$ and $\mathrm{KC}-031$ was $99.9 \%$, and they showed the highest sequence similarities to S. olivochromogenes NBRC $3178^{\mathrm{T}}(98.1 \%)$ and 
S. psammoticus NBRC $13971^{\mathrm{T}}$ (98.1\%) and clustered with them (Figure 1).

The 16S rRNA gene sequence of strain KC- $106^{\mathrm{T}}$ was most similar to those of S. seoulensis NBRC $16668^{\mathrm{T}}(98.9 \%)$, S. recifensis NBRC $12813^{\mathrm{T}}(98.9 \%)$, S. chartreusis NBRC $12753^{\mathrm{T}}(98.7 \%)$ and $S$. griseoluteus NBRC $13375^{\mathrm{T}}$ (98.4\%). The phylogenetic tree showed that strain $\mathrm{KC}-106^{\mathrm{T}}$ forms a cluster with three of the above species, with the exception of $S$. chartreusis (Figure 2).

\section{Phenotypic characteristics}

The cultural characteristics of strains $\mathrm{KC}-038^{\mathrm{T}}$ and $\mathrm{KC}-031$, along with those of the type strains of the closest related species, S. olivochromogenes NBRC $3178^{\mathrm{T} 34}$ and S. psammoticus NBRC $13971^{\mathrm{T}}$, 35 are shown in Table 3. Strains KC-038 ${ }^{\mathrm{T}}$ and KC-031 grew well and formed extensively branched substrate mycelia on the various agar media tested. Aerial mycelia of white to gray color were produced on ISP 2-5 and 7 media, YS agar and nutrient agar, while the related type strains produced white aerial mycelia. The aerial mycelia consisted of long spiral chains with a smooth surface and the spores were rod shaped (Figures 3 and 4). Soluble pigment was produced on ISP 6 medium. The phenotypic and differential characteristics of strains $\mathrm{KC}-038^{\mathrm{T}}$ and KC-031 are listed in the species description below and in Table 4 . Strains $\mathrm{KC}-038^{\mathrm{T}}$ and $\mathrm{KC}-031$ were highly similar to each other but were differentiated from the closest related type strains with respect to carbon utilization.

The cultural characteristics of strain $\mathrm{KC}-106^{\mathrm{T}}$ and the type strains of the closest related species, S. seoulensis NBRC $16668^{\mathrm{T}},{ }^{36}$ S. recifensis



Figure 3 Scanning electron micrograph of strain $\mathrm{KC}^{-} 038^{\top}$ grown on $\mathrm{YS}$ agar for 3 weeks at $27^{\circ} \mathrm{C}$.

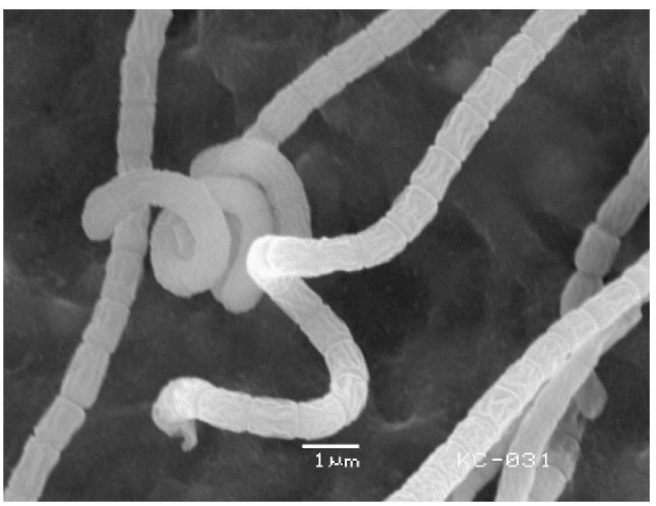

Figure 4 Scanning electron micrograph of strain KC-031 grown on ISP 4 medium for 3 weeks at $27^{\circ} \mathrm{C}$.
NBRC $12813^{\mathrm{T}},{ }^{37}$ S. chartreusis NBRC $12753^{\mathrm{T}}{ }^{38}$ and S. griseoluteus NBRC $13375^{\mathrm{T}},{ }^{39}$ are shown in Table 5 . The strain grew well and formed extensively branched substrate and aerial mycelia on all agar media tested. Aerial mycelia of white to brownish gray color were produced. The aerial mycelia consisted of long and spiral spore chains with a hairy surface and oval-shaped spores (Figure 5), which is clearly different from the smooth spores produced by the related strains. The phenotypic and differential characteristics of strain KC$106^{\mathrm{T}}$ are listed in the species description below and in Table 6. Strain $\mathrm{KC}-106^{\mathrm{T}}$ was also differentiated from the closest related type strains with respect to carbon utilization.

\section{DNA-DNA hybridization}

The DNA-DNA relatedness value between strains $\mathrm{KC}-038^{\mathrm{T}}$ and $\mathrm{KC}-$ 031 was $100 \%$; therefore, these two strains were classified as the same species. The DNA-DNA relatedness values between strain $\mathrm{KC}-038^{\mathrm{T}}$ and the closest related type strains, S. olivochromogenes NBRC $3178^{\mathrm{T}}$ and S. psammoticus NBRC $13971^{\mathrm{T}}$, were in the range of $4-36 \%$ (Table 7). The DNA-DNA relatedness values between strain KC-106 ${ }^{\mathrm{T}}$ and the closest type strains, S. seoulensis NBRC $16668^{\mathrm{T}}$, S. recifensis NBRC $12813^{\mathrm{T}}$, S. chartreusis NBRC $12753^{\mathrm{T}}$ and S. griseoluteus NBRC $13375^{\mathrm{T}}$, were in the range of $7-46 \%$ (Table 8 ). These values were below the $70 \%$ cutoff point recommended by Wayne et al. ${ }^{40}$ for assigning strains to the same species, and these results thus confirm that strains $\mathrm{KC}-038^{\mathrm{T}}$ and $\mathrm{KC}-106^{\mathrm{T}}$ are distinct from their closely related phylogenetic neighbors. Therefore, strains $\mathrm{KC}-038^{\mathrm{T}}$ and $\mathrm{KC}-$ $106^{\mathrm{T}}$ are clearly the two novel species within the genus Streptomyces.

Table 4 Differential characteristics of strains $\mathrm{KC}-038^{\mathrm{T}}$, KC-031 and closely related type strains

\begin{tabular}{|c|c|c|c|c|}
\hline Characteristics & $K C-038^{T}$ & KC-031 & $\begin{array}{c}\text { S. olivochromogenes } \\
\text { NBRC } 3178^{T}\end{array}$ & $\begin{array}{l}\text { S. psammoticus } \\
\text { NBRC } 13971^{T}\end{array}$ \\
\hline Spore chain & Spiral & Spiral & Spiral & Ractiflexibiles \\
\hline Spore surface & Smooth & Smooth & Smooth & Smooth \\
\hline \multicolumn{5}{|l|}{ Utilization of } \\
\hline L-Arabinose & + & + & + & - \\
\hline D-Xylose & + & + & + & - \\
\hline Raffinose & + & + & - & - \\
\hline Melibiose & + & + & + & - \\
\hline D-Mannitol & + & + & + & - \\
\hline L-Rhamnose & + & + & + & - \\
\hline myo-Inositol & + & + & + & - \\
\hline Sucrose & - & - & + & + \\
\hline Gelatin liquefaction & - & - & w & - \\
\hline $\mathrm{NaCl}$ tolerance (\%) & 6 & 6 & 6 & 3 \\
\hline \multicolumn{5}{|l|}{ Enzyme activity of } \\
\hline Esterase lipase C8 & - & w & w & w \\
\hline $\begin{array}{l}\text { Cystine } \\
\text { arylamidase }\end{array}$ & w & w & w & - \\
\hline Trypsin & w & + & - & - \\
\hline$\alpha$-Galactosidase & - & - & w & - \\
\hline$\beta$-Galactosidase & w & + & + & + \\
\hline$\alpha$-Glucosidase & - & w & + & + \\
\hline$\beta$-Glucosidase & + & + & - & - \\
\hline $\begin{array}{l}N \text {-Acetyl- } \beta \text { - } \\
\text { glucosaminidase }\end{array}$ & + & + & w & - \\
\hline$\alpha$-Mannosidase & w & w & - & + \\
\hline
\end{tabular}

Abbreviations: +, positive; w, weakly positive; -, negative. 
Table 5 Cultural characteristics of strain $\mathrm{KC}-106^{\top}$ and closely related type strains

\begin{tabular}{|c|c|c|c|c|c|}
\hline \multirow[b]{2}{*}{ Medium } & \multirow[b]{2}{*}{$K C-106^{T}$} & \multirow[b]{2}{*}{ S. seoulensis NBRC $16668^{T}$} & \multirow[b]{2}{*}{ S. recifensis NBRC $12813^{T}$} & \multicolumn{2}{|l|}{ S. griseoluteus } \\
\hline & & & & NBRC $13375^{T}$ & S. chartreusis NBRC $12753^{T}$ \\
\hline \multicolumn{6}{|l|}{ ISP medium 2} \\
\hline \multirow[t]{2}{*}{ Growth } & Good & Good & Good & Good & Good \\
\hline & Dusty yellow (1/2gc) & Colorless & Colorless & Mustard $\tan (2 \mathrm{ie})$ & Light ivory (2ca) \\
\hline Reverse & $\begin{array}{l}\text { Bamboo (2gc) to mustard } \\
\text { brown }(2 \mathrm{ni})\end{array}$ & Bamboo (2gc) & $\begin{array}{l}\text { Bamboo }(2 \mathrm{gc}) \text { to slate tan } \\
(2 \mathrm{ig})\end{array}$ & $\begin{array}{l}\text { Bamboo }(2 \mathrm{gc}) \text { to mustard } \\
\text { brown }(2 \mathrm{ni})\end{array}$ & $\begin{array}{l}\text { Bamboo }(2 \mathrm{gc}) \text { to light olive } \\
\text { gray }\left(1_{1 / 2} \mathrm{ge}\right)\end{array}$ \\
\hline Aerial mycelium & $\begin{array}{l}\text { Abundant, white (a) to silver } \\
\text { gray (3fe) }\end{array}$ & $\begin{array}{l}\text { Abundant, white (a) to ashes } \\
(5 \mathrm{fe})\end{array}$ & $\begin{array}{l}\text { Abundant, white (a) to lead } \\
\text { gray (5ih) }\end{array}$ & $\begin{array}{l}\text { Abundant, white (a) to } \\
\text { ashes ( } 5 \mathrm{fe})\end{array}$ & $\begin{array}{l}\text { Abundant, white (a) to aqua } \\
\text { gray (19fe) }\end{array}$ \\
\hline Soluble pigment & None & None & None & None & None \\
\hline \multicolumn{6}{|l|}{ ISP medium 3} \\
\hline \multirow[t]{2}{*}{ Growth } & Good & Good & Good & Good & Good \\
\hline & $\begin{array}{l}\text { Light mustard tan (2ie) to } \\
\text { mustard } \tan (2 \mathrm{lg})\end{array}$ & Convert tan (2ge) & Colorless & Biscuit (2ec) & $\begin{array}{l}\text { Light ivory (2ca) to bamboo } \\
\text { (2gc) }\end{array}$ \\
\hline Reverse & Beige (3ge) & Ivory (2db) to convert $\tan (2 \mathrm{ge})$ & Pearl (3ba) to natural (2dc) & $\begin{array}{l}\text { Ivory ( } 2 \mathrm{db}) \text { to convert brown } \\
\text { (2li) }\end{array}$ & $\begin{array}{l}\text { Light ivory (2ca) to light mus- } \\
\text { tard } \tan (2 \mathrm{ie})\end{array}$ \\
\hline Aerial mycelium & Abundant, fawn (4ig) & Abundant, ashes (5fe) & $\begin{array}{l}\text { Abundant, white (a) to silver } \\
\text { gray (3fe) }\end{array}$ & $\begin{array}{l}\text { Abundant, white (a) to lead } \\
\text { gray (5ih) }\end{array}$ & $\begin{array}{l}\text { Abundant, white (a) to down } \\
\text { blue ( } 15 \mathrm{dc})\end{array}$ \\
\hline Soluble pigment & None & None & None & None & None \\
\hline \multicolumn{6}{|l|}{ ISP medium 4} \\
\hline \multirow[t]{2}{*}{ Growth } & Good & Good & Good & Good & Good \\
\hline & Light mustard tan (2ie) & Convert gray (2fe) & $\begin{array}{l}\text { Light ivory (2ca) to ivory } \\
(2 \mathrm{db})\end{array}$ & Bisque (3ec) to camel (3ie) & Ivory (2db) \\
\hline Reverse & $\begin{array}{l}\text { Light ivory (2ca) to mustard } \\
\tan (2 \mathrm{lg})\end{array}$ & Ivory (2db) to slate $\tan (2 \mathrm{ig}$ ) & Ivory (2db) & Light fawn (4ge) & Ivory (2db) \\
\hline Aerial mycelium & $\begin{array}{l}\text { Abundant, white (a) to silver } \\
\text { gray (3fe) }\end{array}$ & $\begin{array}{l}\text { Abundant, white (a) to ashes } \\
\text { (5fe) }\end{array}$ & Abundant, white (a) & Abundant, white (a) & Abundant, white (a) to gray(e) \\
\hline Soluble pigment & None & None & None & None & None \\
\hline \multicolumn{6}{|l|}{ ISP medium 5} \\
\hline \multirow[t]{2}{*}{ Growth } & Good & Good & Good & Good & Good \\
\hline & Pearl (3ba) to mustard (2le) & Pearl (3ba) & Convert gray (2fa) & Pearl (3ba) & White (a) to ivory (2db) \\
\hline Reverse & $\begin{array}{l}\text { Pearl (3ba) to light fawn } \\
\text { (4ge) }\end{array}$ & Sand $(3 \mathrm{cb})$ to silver gray $(3 \mathrm{fe})$ & Natural (2dc) & Pearl (3ba) to ashes (5fe) & White (a) to light ivory (2ca) \\
\hline Aerial mycelium & $\begin{array}{l}\text { Abundant, white (a) to silver } \\
\text { gray ( } 3 \mathrm{fe} \text { ) }\end{array}$ & Abundant, white (a) & $\begin{array}{l}\text { Abundant, Natural (3dc) to } \\
\text { silver gray ( } 3 \mathrm{fe} \text { ) }\end{array}$ & $\begin{array}{l}\text { Abundant, white (a) to lead } \\
\text { gray (3ih) }\end{array}$ & Moderate, white (a) \\
\hline Soluble pigment & None & None & None & None & None \\
\hline \multicolumn{6}{|l|}{ ISP medium 6} \\
\hline \multirow{2}{*}{ Growth } & Good & Good & Good & Good & Good \\
\hline & Light ivory (2ca) & Cream $\left(1_{1 / 2} \mathrm{Ca}\right)$ & Colorless & Cream $\left(1_{1 / 2} \mathrm{ca}\right)$ & Light ivory (2ca) \\
\hline Reverse & Light wheat (2ea) & $\begin{array}{l}\text { Cream }\left(1_{1 / 2} \mathrm{ca}\right) \text { to light wheat } \\
\text { (2ea) }\end{array}$ & Light ivory (2ca) & Light wheat (2ea) & Light ivory (2ca) \\
\hline Aerial mycelium & Abundant, white (a) & Abundant, white (a) & Abundant, white (a) & Abundant, white (a) & None \\
\hline Soluble pigment & None & None & None & None & None \\
\hline \multicolumn{6}{|l|}{ ISP medium 7} \\
\hline \multirow[t]{2}{*}{ Growth } & Good & Good & Good & Good & Good \\
\hline & $\begin{array}{l}\text { Cream }\left(1_{1 / 2} \mathrm{ca}\right) \text { to mustard } \\
\text { (2le) }\end{array}$ & Pearl (3ba) & Sand $(3 \mathrm{cb})$ & Pearl (3ba) & $\begin{array}{l}\text { Golden brown (3pi) to clover } \\
\text { brown }(3 \mathrm{pl})\end{array}$ \\
\hline Reverse & Ivory (2dc) to mustard (2le) & Pearl (3ba) to natural (3dc) & Natural (3dc) & Pearl (3ba) to slate $\tan (2 \mathrm{ig})$ & Beige (3gc) to beaver (4li) \\
\hline Aerial mycelium & $\begin{array}{l}\text { Abundant, white (a) to silver } \\
\text { gray ( } 3 \mathrm{fe} \text { ) }\end{array}$ & $\begin{array}{l}\text { Abundant, natural (3dc) to sil- } \\
\text { ver gray ( } 3 f \mathrm{fe})\end{array}$ & Abundant, natural (3dc) & $\begin{array}{l}\text { Abundant, white (a) to silver } \\
\text { gray ( } 3 \mathrm{fe} \text { ) }\end{array}$ & $\begin{array}{l}\text { Abundant, natural (3dc) to } \\
\text { dawn blue ( } 15 \mathrm{dc})\end{array}$ \\
\hline Soluble pigment & None & None & None & None & None \\
\hline \multicolumn{6}{|l|}{ YS agar } \\
\hline \multirow[t]{2}{*}{ Growth } & Good & Good & Good & Good & Good \\
\hline & Light mustard tan (2ie) & Convert tan (2ge) & Colorless & Ivory (2db) & Pearl (3ba) to light ivory (2ca) \\
\hline Reverse & $\begin{array}{l}\text { Mustard tan (2lg) to mus- } \\
\text { tard brown }(2 n i)\end{array}$ & Beige (3ge) to dark brown (3nl) & $\begin{array}{l}\text { Ivory }(2 \mathrm{db}) \text { to dark brown } \\
(3 \mathrm{nl})\end{array}$ & $\begin{array}{l}\text { Bisque (3ec) to dark brown } \\
(3 \mathrm{nl})\end{array}$ & Biscuit (2ec) \\
\hline Aerial mycelium & $\begin{array}{l}\text { Abundant, white (a) to silver } \\
\text { gray (3fe) }\end{array}$ & $\begin{array}{l}\text { Abundant, white (a) to lead } \\
\text { gray (5ih) }\end{array}$ & $\begin{array}{l}\text { Abundant, white(a) to ashes } \\
\text { (5fe) }\end{array}$ & $\begin{array}{l}\text { Abundant, white (a) to lead } \\
\text { gray (5ih) }\end{array}$ & $\begin{array}{l}\text { Abundant, white (a) to aqua } \\
\text { gray (19fe) }\end{array}$ \\
\hline Soluble pigment & None & None & None & None & None \\
\hline Nutrient agar & & & & & \\
\hline Growth & Good & Good & Good & Good & Good \\
\hline & Ivory (2db) to biscuit (2ec) & Pearl (2cb) & Pearl (2cb) & Pearl (3ba) & Cream $\left(1_{1 / 2} \mathrm{ca}\right)$ \\
\hline Reverse & $\begin{array}{l}\text { Bamboo }(2 \mathrm{gc}) \text { to light mus- } \\
\operatorname{tard} \tan (2 \mathrm{ie})\end{array}$ & Light ivory (2ca) & $\begin{array}{l}\text { Light ivory (2ca) to convert } \\
\tan (2 \mathrm{ge})\end{array}$ & Pearl (3ba) & Cream $\left(1_{1 / 2} \mathrm{ca}\right)$ \\
\hline Aerial mycelium & $\begin{array}{l}\text { Abundant, white (a) to silver } \\
\text { gray (3fe) }\end{array}$ & Abundant, white (a) & $\begin{array}{l}\text { Abundant, white (a) to silver } \\
\text { gray (3fe) }\end{array}$ & Abundant, white (a) & Poor, white (a) \\
\hline Soluble pigment & None & None & None & None & None \\
\hline
\end{tabular}

Numbers and letters in parentheses referred to the color based on the Color Harmony Manual. ${ }^{22}$

\section{Conclusion}

Based on phylogenetic, phenotypic and chemotaxonomic characteristics, strains $\mathrm{KC}-038^{\mathrm{T}}$, KC-031 and $\mathrm{KC}-106^{\mathrm{T}}$ are classified within the genus Streptomyces. The cultural, physiological and biochemical features, such as aerial mycelia color and utilization of various carbohydrates as the sole carbon source, indicate that strains $\mathrm{KC}$ $038^{\mathrm{T}}, \mathrm{KC}-031$ and $\mathrm{KC}-106^{\mathrm{T}}$ differ from the closest related species. The results of DNA-DNA relatedness also support their classification of these strains into two novel species. Therefore, the name Streptomyces siamensis sp. nov. is proposed for strains $\mathrm{KC}-038^{\mathrm{T}}$ and $\mathrm{KC}-031$, and the name Streptomyces similanensis sp. nov. is proposed for strain $\mathrm{KC}-106^{\mathrm{T}}$.

Description of $S$. siamensis sp. nov. (si.am.en'sis N.L. masc. adj. siamensis, belonging to Siam, the old name for Thailand, where the first strain was isolated)

Gram-positive, aerobic actinomycete, forming extensively branched substrate mycelia and aerial hyphae that differentiate into long and 
spiral chains of smooth-surfaced, rod-shaped spores. The color of aerial mycelia varies from white to gray. Dark brown soluble pigment is produced in ISP6 medium. Growth occurs at $16-38^{\circ} \mathrm{C}$ (optimum at $16-30^{\circ} \mathrm{C}$ ) and at $\mathrm{pH} 4-11$ (optimum at $\mathrm{pH} 5-9$ ). Hydrolyzes casein and starch but not gelatin. Nitrate is not reduced. Utilizes D-glucose, L-arabinose, D-xylose, raffinose, melibiose, D-mannitol, D-fructose, L-rhamnose and myo-inositol, but not sucrose. Positive for alkaline phosphatase, esterase (C4), leucine arylamidase, acid phosphatase, naphthol-AS-BI-phosphohydrase, $\beta$-glucosidase and $N$-acetyl- $\beta$-glucosaminidase, and weakly positive for valine

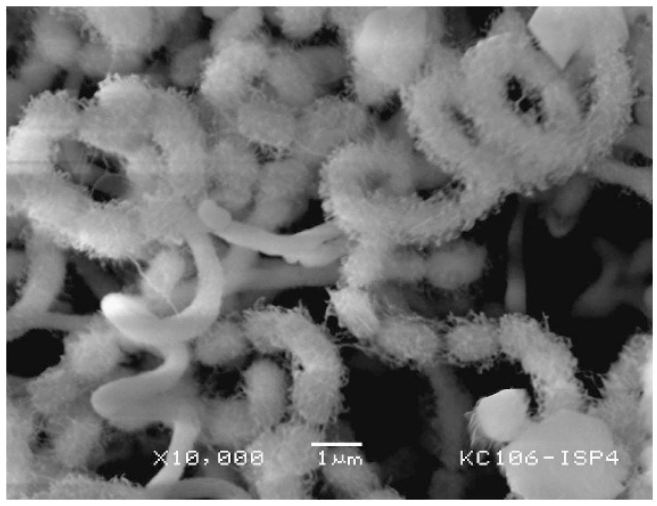

Figure 5 Scanning electron micrograph of strain $\mathrm{KC}-106^{\top}$ grown on ISP 4 medium for 3 weeks at $27^{\circ} \mathrm{C}$. arylamidase, cystine arylamidase, trypsin, $\beta$-galactosidase and $\alpha$-mannosidase. Negative for esterase lipase (C8), lipase (C14), osidase, $\alpha$-galactosidase and $\alpha$-glucosidase (API ZYM system). The menaquinones are MK-9 $\left(\mathrm{H}_{6}\right)$, MK-9 $\left(\mathrm{H}_{4}\right)$ and MK-9 $\left(\mathrm{H}_{8}\right)$. Major cellular fatty acids are $\mathrm{C}_{16: 0}$, iso- $\mathrm{C}_{16: 0}$ and anteiso- $\mathrm{C}_{15: 0}$. The DNA G $+\mathrm{C}$ content of the type strain is $72 \mathrm{~mol} \%$.

The type strain $\mathrm{KC}-038^{\mathrm{T}}\left(=\mathrm{NBRC} 108799^{\mathrm{T}}=\mathrm{PCU} 328^{\mathrm{T}}\right.$ $=$ TISTR $2107^{\mathrm{T}}$ ) was isolated from the soil collected at Krung Ching Waterfall, Khao Luang National Park, Nakhon Si Thammarat Province, Thailand.

Table 7 DNA-DNA relatedness between $\mathrm{KC}-038^{\top}, \mathrm{KC}-031$ and closely related type strains

\begin{tabular}{lrrrc}
\hline & \multicolumn{4}{c}{ DNA-DNA relatedness with labeled strains (\%) } \\
\cline { 2 - 5 } Strain & KC- & KC- & S. olivochromogenes & S. psammoticus \\
& $038^{T}$ & 031 & NBRC 3178 & NBRC $13971^{T}$ \\
\hline KC-038 $^{\top}$ & 100 & 100 & 36 & 13 \\
KC-031 $^{*}$ olivochromogenes & 100 & 100 & 11 & 3 \\
NBRC 3178 & 17 & 21 & 100 & 4 \\
S. psammoticus & 4 & 9 & 2 & 100 \\
NBRC 13971 & & & & \\
\hline
\end{tabular}

average of four independent determinations.

Table 6 Differential characteristics of strain $\mathrm{KC}-106^{\top}$ and closely related type strains

\begin{tabular}{|c|c|c|c|c|c|}
\hline Characteristicc & $K C-10 \sigma^{T}$ & S. seoulensis & S. recifensis & S. griseoluteus & S. chartreusis \\
\hline 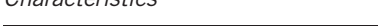 & & & & & \\
\hline Spore chain & Spiral & Ractiflexibiles & Retinaculiaperti & Ractiflexibiles & Spiral \\
\hline Spore surface & Hairy & Smooth & Smooth & Smooth & Spiny \\
\hline \multicolumn{6}{|l|}{ Utilization of } \\
\hline Raffinose & w & + & w & w & + \\
\hline Melibiose & w & + & - & w & + \\
\hline L-Rhamnose & - & + & - & - & + \\
\hline myo-Inositol & - & - & - & - & + \\
\hline Sucrose & w & + & + & w & + \\
\hline Nitrate reduction & - & - & - & - & + \\
\hline Gelatin liquefaction & - & + & + & w & + \\
\hline $\mathrm{NaCl}$ tolerance (\%) & 7 & 8 & 6 & 5 & 6 \\
\hline \multicolumn{6}{|l|}{ Enzyme activity of } \\
\hline Alkaline phosphatase & + & + & + & - & + \\
\hline Esterase $\mathrm{C} 4$ & + & + & + & w & + \\
\hline Esterase lipase C8 & - & + & w & - & w \\
\hline Valine arylamidase & + & w & + & + & w \\
\hline Cystine arylamidase & + & w & + & + & w \\
\hline Trypsin & - & - & w & - & + \\
\hline$\alpha$-Chymotrypsin & - & - & - & - & + \\
\hline Naphthol-AS-BI-phosphohydrase & + & + & + & w & + \\
\hline$\beta$-Galactosidase & - & - & + & - & + \\
\hline$\alpha$-Glucosidase & + & w & + & - & - \\
\hline$\beta$-Glucosidase & + & - & - & - & + \\
\hline$N$-acetyl- $\beta$-glucosaminidase & + & + & + & w & + \\
\hline$\alpha$-Mannosidase & + & - & - & - & w \\
\hline
\end{tabular}

Abbreviations: + , positive; w, weakly positive; -, negative. 
Table 8 DNA-DNA relatedness between $\mathrm{KC}-106^{\top}$ and closely related type strains

$D N A-D N A$ relatedness with labeled strains $(\%)^{a}$

Strain

KC-106 ${ }^{T}$ S. seoulensis S. recifensis S. griseoluteus S. chartreusis NBRC NBRC

\begin{tabular}{lccccc} 
& & NBRC & NBRC & NBRC & NBRC \\
& & $16668^{T}$ & $12813^{T}$ & $13375^{T}$ & $12753^{T}$ \\
\hline KC-106 $^{\top}$ & 100 & 30 & 28 & 19 & 18 \\
S. seoulensis & 46 & 100 & 67 & 61 & 14 \\
$\begin{array}{l}\text { NBRC 16668 } \\
\text { S. recifensis NBRC }\end{array}$ & 39 & 81 & 100 & 71 & 21 \\
$\begin{array}{l}\text { 12813 } \\
\text { S. griseoluteus }\end{array}$ & 38 & 92 & 96 & 100 & 21 \\
NBRC 13375 & & 24 & 20 & 24 & 100 \\
S. chartreusis & 7 & 24 & & & \\
NBRC 12753 & & & & &
\end{tabular}

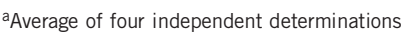

Description of S. similanensis sp. nov. (si.mi.lan. en' sis N.L. masc. adj. similanensis, belonging to Similan, an island in the southern Thailand, where the first strain was isolated)

Gram-positive, aerobic actinomycete, forms extensively branched substrate mycelia and aerial hyphae that differentiate into long and spiral chains of hairy surfaced and oval spores. Aerial mycelia are white to brownish gray in color. Soluble pigment is not produced. Growth occurs at $12-40{ }^{\circ} \mathrm{C}$ (optimum at $18-30^{\circ} \mathrm{C}$ ) and at $\mathrm{pH} 4-11$ (optimum at $\mathrm{pH} 4-9$ ). Hydrolyzes casein and starch but not gelatin. Nitrate is not reduced. Utilizes D-glucose, L-arabinose, D-xylose, raffinose, melibiose, D-mannitol and D-fructose; weakly utilizes raffinose and melibiose, but not sucrose, L-rhamnose or myo-inositol. Positive for alkaline phosphatase, esterase (C4), leucine arylamidase, valine arylamidase, cystine arylamidase, acid phosphatase, naphtholAS-BI-phosphohydrase, $\alpha$-glucosidase, $\beta$-glucosidase, $N$-acetyl- $\beta$-glucosaminidase and $\alpha$-mannosidase. Negative for esterase lipase (C8), trypsin, $\alpha$-chymotrypsin and $\beta$-galactosidase (API ZYM system). Menaquinones are MK-9 $\left(\mathrm{H}_{8}\right)$, MK-9 $\left(\mathrm{H}_{6}\right)$ and MK-9 $\left(\mathrm{H}_{4}\right)$. Major cellular fatty acids are anteiso- $\mathrm{C}_{15: 0}$, iso- $\mathrm{C}_{16: 0}$ and anteiso- $\mathrm{C}_{17: 0}$. The DNA G + C content is $73 \mathrm{~mol} \%$.

The type strain $\mathrm{KC}-106^{\mathrm{T}}\left(=\mathrm{NBRC} 108798^{\mathrm{T}}=\mathrm{PCU} 329^{\mathrm{T}}=\mathrm{TISTR}\right.$ $2104^{\mathrm{T}}$ ) was isolated from soil collected at the Similan Island National Park, Phanga Province, Thailand.

\section{ACKNOWLEDGEMENTS}

This research was supported by a Chulalongkorn University Duthsadiphiphat Scholarship (2008), Chulalongkorn University, Bangkok, Thailand, and by the Kitasato Institute for Life Sciences, Kitasato University, Japan. We thank Professor JP Euzeby for the etymologies.

1 Waksman, S. A. \& Henrici, A. T. The nomenclature and classification of actinomycetes. J. Bacteriol. 46, 337-341 (1943).

2 Kim, B.-Y., Zucchi, T. D., Fiedler, H.-P. \& Goodfellow, M. Streptomyces cocklensis sp. nov., a dioxamycin-producing actinomycete. Int. J. Syst. Evol. Microbiol. 62, 279-283 (2012).

3 Lee, H.-J., Han, S.-I. \& Whang, K.-S. Streptomyces gramineus sp. nov., an antibiotic producing actinobacterium isolated from bamboo (Sasa borealis) rhizosphere soil. Int J. Syst. Evol. Microbiol. 62, 856-859 (2012).

4 Tian, X.-P. et al. Streptomyces nanhaiensis sp. nov., a marine streptomycete isolated from a deep-sea sediment. Int. J. Syst. Evol. Microbiol. 62, 864-868 (2012).

5 Cui, Y. et al. Streptomyces panacagri sp. nov., isolated from soil of a ginseng field. Int. J. Syst. Evol. Microbiol. 62, 780-785 (2012).

6 Carro, L., Zuniga, P., Calle, F. D. L. \& Trujillo, M. E. Streptomyces pharmamarensis sp. nov.isolated from a marine sediment. Int. J. Syst. Evol. Microbiol. 62, 1165-1170 (2012)
$7 \mathrm{Hu}, \mathrm{H}$. et al. Streptomyces qinglanensis sp. nov., isolated from mangrove sediment. Int. J. Syst. Evol. Microbiol. 62, 596-600 (2012).

8 Kim, B.-Y., Zucchi, T. D., Fiedler, H.-P. \& Goodfellow, M. Streptomyces staurosporininus sp. nov., a staurosporine-producing actinomycete. Int. J. Syst. Evol. Microbiol. 62, 966-970 (2012).

9 Berdy, J. Bioactive microbial metabolites: review article. J. Antibiot. 58, 1-26 (2005)

10 Tajima, K., Takahashi, Y., Seino, A., Iwai, Y. \& Omura, S. Description of two nove species of the genus Kitasatospora Omura et al. 1982, Kitasatospora cineracea sp. nov. and Kitasatospora niigatensis sp. nov. Int. J. Syst. Evol. Microbiol 51, 1765-1771 (2001).

11 Seong, C. N., Choi, J. H. \& Baik, K.-S. An improved selective isolation of rare actinomycetes from forest soil. J. Microbiol. 39, 17-23 (2001).

12 Matsumoto, A., Takahashi, Y., Iwai, Y. \& Omura, S. Isolation of Gram-positive bacteria with high $\mathrm{G}+\mathrm{C}$ from inside soil aggregates. Actinomycetologica 20, 30-40 (2006).

13 Takahashi, Y. et al. Streptomyces avermectinius sp. nov., an avermectin-producing strain. Int. J. Syst. Evol. Microbiol. 52, 2163-2168 (2002).

$14 \mathrm{Kim}, \mathrm{O}$. S. et al. Introducing EzTaxon-e: a prokaryotic 16S rRNA gene sequence database with phylotypes that represent uncultured species. Int. J. Syst. Evol. Microbiol. 62, 716-721 (2012).

15 Kimura, M. A simple method for estimating evolutionary rates of base substitutions through comparative studies of nucleotide sequences. J. Mol. Evol. 16, 111-120 (1980).

16 Gouy, M., Gascuel, S. \& Gascuel, 0. SeaView version 4.2: a multiplateform graphical user interface for sequence alignment and phylogenetic tree building. Mol. Biol. Evol. 27, 221-224 (2010).

17 Saito, N. \& Nei, M. The neighbor-joining method: a new method for reconstructing phylogenetic trees. Mol. Biol. Evol. 4, 406-425 (1987).

18 Felsenstein, J. Evolutionary trees from DNA sequences: a maximum likelihood approach. J. Mol. Evol. 17, 368-379 (1981).

19 Kluge, A. G. \& Farris, F. S. Quantitative phyletics and the evolution of anurans. Syst Zool. 18, 1-32 (1969).

20 Felsenstein, J. Confidence limits on phylogenies: an approach using the bootstrap. Evolution. 39, 783-791 (1985).

21 Shirling, E. B. \& Gottlieb, D. Methods for characterization of Streptomyces species. Int J. Syst. Bacteriol. 16, 313-340 (1966).

22 Taylor, H. D., Knoche, L. \& Grauville, W. C. Color Harmony Manual. 4th edn (Container Corporation of America, Chicago, IL, USA, 1958).

23 Inahashi, Y., Matsumoto, A., Danbara, H., Omura, S. \& Takahashi, Y. Phytohabitans suffuscus gen. nov., sp. nov., an actinomycete of the family Micromonosporaceae isolated from plant roots. Int. J. Syst. Evol. Microbiol. 60, 2652-2658 (2010).

24 Pridham, T. G. \& Gottlieb, D. The utilization of carbon compounds by some Actinomycetales as an aid for species determination. J. Bacteriol 56, 107-114 (1948)

25 Becker, B., Lechevalier, M. P. \& Lechevalier, H. A. Chemical composition of cell-wal preparation from strains of various from-genera of aerobic actinomycetes. Appl. Microbiol. 13, 236-243 (1965).

26 Collins, M. D., Pirouz, T., Goodfellow, M. \& Minnikin, D. E. Distribution of menaquinones in actinomycetes and corynebacteria. J. Gen. Microbiol. 100 221-230 (1977)

27 Uchida, K. \& Aida, K. Acyl type of bacterial cell wall: its simple identification by a colorimetric method. J. Gen. Appl. Microbiol. 23, 249-260 (1977).

28 Minnikin, D. E., Patel, P. V., Alshamaony, L. \& Goodfellow, M. Polar lipid composition in the classification of Nocardia and related bacteria. Int. J. Syst. Bacteriol. 27, 104-117 (1977)

29 Tomiyasu, I. Mycolic acid composition and thermally adaptative changes in Nocardia asteroids. J. Bacteriol. 151, 828-837 (1982).

30 Sasser, M. Identification of bacteria by gas chromatography of cellular fatty acids. USFCC News/ 20, 1-6 (1990).

31 Saito, H. \& Miura, K. Preparation of transforming deoxyribonucleic acid by phenol treatment. Biochim. Biophys. Acta. 72, 619-629 (1963).

32 Tamaoka, J. \& Komagata, K. Determination of DNA base composition by reversedphase high-performance liquid chromatography. FEMS Microbiol. Lett. 25, 125-128 (1984)

33 Ezaki, T., Hashimoto, Y. \& Yabuuchi, E. Fluorometric deoxyribonucleic acid-deoxyribonucleic acid hybridization in microdilution wells as an alternative to membrane filter hybridization in which radioisotopes are used to determine genetic relatedness among bacterial strains. Int. J Syst. Bacteriol. 39, 224-229 (1989).

34 Shirling, E. B. \& Gottlieb, D. Cooperative description of type cultures of Streptomyces. IV. Species descriptions from the second, third and fourth studies. Int. J. Syst. Bacteriol. 19, 391-512 (1969).

35 Virgilio, A. \& Hengeller, C. Produzione di Tetraciclina con Streptomyces psammoticus. Farm. Ediz. Scient. 15, 164-174 (1960)

36 Chun, J. et al. Streptomyces seoulensis sp. nov. Int. J. Syst. Bacteriol. 47, 492-498 (1997)

37 Shirling, E. B. \& Gottlieb, D. Cooperative description of type cultures of Streptomyces. II. Species descriptions from first study. Int. J. Syst. Bacteriol. 18, 69-189 (1968).

38 Leach, B. E., Calhoun, K. M., Johnson, L. E., Teeters, C. M. \& Jackson, W. G. Chartreusin, a new antibiotic produced by Streptomyces chartreusis a new species. J. Am. Chem. Soc. 75, 4011-4012 (1953).

39 Umezawa, H., Hayano, S., Maeda, K., Ogata, Y. \& Okami, Y. On a new antibiotic, griseolutein, produced by Streptomyces. Jpn. Med. J. 3, 111-117 (1950).

40 Wayne, L. G. et al. International Committee on Systematic Bacteriology. Report of the Ad Hoc Committee on reconciliation of approaches to bacterial systematics. Int. J.Syst. Bacteriol. 37, 463-464 (1987). 